\title{
Insulin-like growth factor-I, but not growth hormone, is dependent on a high protein intake to increase nitrogen balance in the rat
}

\author{
Myriam Sanchez-Gomez ${ }^{1}$, Kjell Malmlöf ${ }^{2 *}$, Wilson Mejia ${ }^{1}$, Antonio Bermudez ${ }^{1}$, Maria Teresa Ochoa ${ }^{1}$, \\ Stella Carrasco-Rodriguez ${ }^{1}$ and Anna Skottner ${ }^{2} \dagger$ \\ ${ }^{1}$ Department de Chemistry, Universidad Nacional de Colombia, Santafé de Bogotá, Colombia. \\ ${ }^{2}$ Department of Pharmacology, Peptide Hormones, Pharmacia, Stockholm, Sweden
}

(Received 15 June 1998 - Revised 28 August 1998 - Accepted 15 September 1998)

\begin{abstract}
The aim of the present study was to investigate the influence of dietary protein level on the protein anabolic effects of growth hormone $(\mathrm{GH})$ and insulin-like growth factor-I (IGF-I). Female growing rats were fed on either a high- or a low-protein diet with crude protein contents of 222 and $83 \mathrm{~g} / \mathrm{kg}$ respectively. The diets contained the same amount of metabolizable energy $(15 \cdot 1 \mathrm{MJ} /$ $\mathrm{kg}$ ) and were given during a $14 \mathrm{~d}$ period. During the same time, three groups of rats $(n 8)$ on each diet received subcutaneous infusions of either saline, recombinant human $\mathrm{GH}$ (rhGH) or recombinant human IGF-I (rhIGF-I). rhGH and rhIGF-I were given in doses of 360 and $500 \mu \mathrm{g} / \mathrm{d}$ respectively. The low-protein diet alone reduced significantly $(P<0.05)$ IGF-I concentrations in serum and in tissue taken from the gastrocnemius muscle as well as IGF-I mRNA from the same muscle. The responses to rhGH and rhIGF-I in terms of muscle IGF-I and its mRNA were variable. However, when rhIGF-I was infused into rats on the high-protein diet, significantly elevated levels of IGF-I in muscle tissues could be observed. This was associated with a significantly $(P<0.05)$ increased $\mathrm{N}$ balance, whereas rhGH significantly $(P<0.05)$ enhanced the $\mathrm{N}$ balance in rats on the low-protein diet. Thus, it can be concluded that the level of dietary protein ingested regulates not only the effect of IGF-I on whole-body $\mathrm{N}$ economy but also the regulation of IGF-I gene expression in muscles. The exact mechanism by which GH exerts its protein anabolic effect, however, remains to be elucidated.
\end{abstract}

Dietary protein: Growth hormone: Insulin-like growth factor: Nitrogen balance

Growth hormone $(\mathrm{GH})$, insulin and insulin-like growth factor-I (IGF-I) are all known to promote protein accretion and growth (Gelfand \& Barret, 1987; Press, 1988; Daughaday \& Rotwein, 1989; Fryburg et al. 1991). The precise mechanism by which $\mathrm{GH}$ influences the rate of protein anabolism is, as yet, not completely defined. However, IGF-I is thought to be an important intermediate. This has been shown to stimulate growth of hypophysectomized animals (Skottner et al. 1987) and the proliferation of satellite cells in skeletal muscle (Dodson et al. 1985).

It is well established that skeletal muscle is a target tissue for GH. The regulation by GH of the level of IGF-I mRNA in rat heart and skeletal muscle (Isgaard et al. 1989) adds further support to the hypothesis that locally produced IGF-I might be a local mediator for the direct stimulatory effect of $\mathrm{GH}$ on the growth and development of muscle. Furthermore, it has been shown that IGF-I is able to elicit metabolic effects in skeletal muscle, regulating the amino acid and glucose supply (Dardevet et al. 1994) and promoting a net positive protein balance (Pell \& Bates, 1992).

It has also been shown that the serum level of IGF-I is sensitive to changes in nutritional status (Clemmons \& Underwood, 1991). However, the serum concentrations change slowly over hours and days, rather than rapidly within minutes, as in the case of insulin. In protein-restricted rats, the reduced plasma IGF-I levels are accompanied by a decline in the amount of liver and muscle IGF-I mRNA (VandeHaar et al. 1991). The decrease in liver IGF-I mRNA in fasted rats is matched by a similar decrease in IGF-I nuclear transcripts, suggesting an impairment of the expression of the growth factor gene at the transcriptional level (Hayden et al. 1994). There are reports indicating that the stimulation of circulating IGF-I concentrations by GH does not occur in nutritionally deprived animals (Pell \& Bates,

\footnotetext{
Abbreviations: GH, growth hormone; HP, high protein; IGF-I, insulin-like growth factor-I; LP, low protein; rhGH, recombinant human growth hormone; rhIGF-I, recombinant human insulin-like growth factor-I

* Corresponding author: Dr Kjell Malmlöf, present address Novo Nordisk A/S, GH Biology, Niels Steensens Vej 8, 2820 Gentofte, Denmark, fax +45 4443 80 06, email Kmal@novo.dk

$\dagger$ Present address: Astra Hässle AB, Mölndal, Sweden.
} 
1992; Tomas et al. 1993) or in surgically traumatized pigs (Malmlöf et al. 1995), although other authors claim the contrary (Grant et al. 1991; MacRae et al. 1991). Thus, this question needs more elaboration.

The present study was undertaken to determine the relative contribution of dietary protein intake to the modulation of the anabolic effects of GH and IGF-I in rats and to determine whether any relationship exists between $\mathrm{N}$ balance and the expression of IGF-I in skeletal muscle.

\section{Materials and methods}

\section{Animals and protocol}

Forty-eight female Sprague-Dawley rats (Alab, Stockholm, Sweden) weighing approximately $150 \mathrm{~g}$ were randomly divided into two diet groups of twenty-four animals each. One group was given a diet containing $82 \mathrm{~g}$ crude protein $/ \mathrm{kg}$ (LP) and the other group received a diet containing $222 \mathrm{~g}$ crude protein $/ \mathrm{kg}$ (HP) (Table 1). The two diet groups were then divided into three sub-groups $(n 8)$ and were subcutaneously infused with either saline $(9 \mathrm{~g} \mathrm{NaCl} / \mathrm{l})$, recombinant human GH (rhGH) or recombinant human IGF-I (rhIGF-I). Rats were individually housed in steel metabolism cages which allowed quantitative collection of excreta, and were subjected to a light-dark cycle of $12 / 12 \mathrm{~h}$ at a constant temperature of $+22^{\circ}$. Animals were given their diets in a milled form and had free access to tap water.

\section{Hormone infusions}

rhGH and rhIGF-I (Genotropin ${ }^{\circledR}$ and Igef ${ }^{\circledR}$, Pharmacia, Kabi Peptide Hormones, Stockholm, Sweden) were dissolved in saline solution and administered via osmotic mini pumps delivering $14 \mu \mathrm{l}$ solution/d for $14 \mathrm{~d}$. Concentrations of the hormones used were $25.7 \mathrm{mg} \mathrm{rhGH} / \mathrm{ml}$ and $35.7 \mathrm{mg}$ rhIGF-I/ml resulting in daily doses of 360 and $500 \mu \mathrm{g}$ GH and IGF-I respectively. Control animals were given saline solution alone.

Table 1. Composition of diets

\begin{tabular}{|c|c|c|}
\hline Diets... & High protein (HP) & Low protein (LP) \\
\hline \multicolumn{3}{|l|}{ Diet ingredients (g/kg) } \\
\hline Maize & 670 & 842 \\
\hline Casein & 179 & \\
\hline Wheat bran & 48 & 48 \\
\hline Rapeseed oil & 83 & 90 \\
\hline Minerals and vitamins* & 20 & 20 \\
\hline Metabolizable energy $(\mathrm{MJ} / \mathrm{kg}) \dagger$ & $15 \cdot 1$ & $15 \cdot 1$ \\
\hline Crude protein $(\mathrm{g} / \mathrm{kg})$ & 222 & 82 \\
\hline \multicolumn{3}{|c|}{ 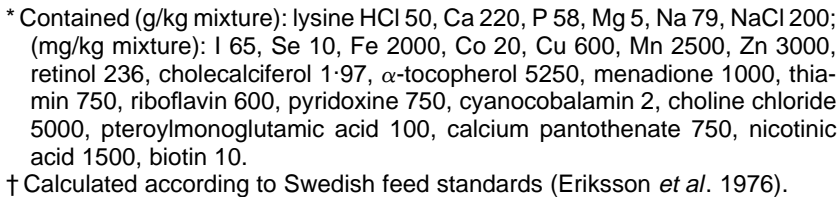 } \\
\hline
\end{tabular}

\section{Surgery}

On day 0 , rats were anaesthetized intraperitoneally with $4 \mathrm{ml} / \mathrm{kg}$ body weight of Rompun $(20 \mathrm{mg} / \mathrm{ml})-$ Ketalar $(50 \mathrm{mg} / \mathrm{ml})$-saline $(9 \mathrm{~g} \mathrm{NaCl} / \mathrm{l})(1: 2: 3$, by vol.). The back of the animal was shaved and the skin was thoroughly washed with chlorohexidine and an iodine solution diluted in ethanol $(700 \mathrm{ml} / \mathrm{l})$. Osmotic mini pumps (Alzet 2002, Alza Corporation, Palo Alto, CA, USA) were implanted in a subcutaneous pocket made between the subcutaneous muscle layer and the fascia. The wound was closed with sutures (Suturamid 4-0; Johnson and Johnson, Sollentuna, Sweden).

\section{Feed and excreta measurements}

Individual feed rations for the whole experimental period were weighed. At the end of the experiment (day 14) the refusals were weighed and feed consumption was calculated. Body-weight gain was recorded every third day. Urine and faeces were collected every day, pooled individually and stored at $-20^{\circ}$ until analysed for total $\mathrm{N}$.

\section{Sampling of blood and tissues}

On days 0 and 14, blood samples were taken from the orbital plexus under diethyl ether anaesthesia. A sample volume of $1.2 \mathrm{ml}$ was allowed to clot at $4^{\circ}$ for $4 \mathrm{~h}$. After centrifugation the samples were decanted and serum frozen at $-30^{\circ}$ until analyses. On day 14 when animals were still influenced by diethyl ether they were killed by $\mathrm{CO}_{2}$ asphyxiation. After this both gastrocnemius muscles were quickly cut out, frozen in liquid $\mathrm{N}_{2}$ and stored at $-70^{\circ}$ until analysis of IGF-I and its mRNA.

\section{Total nitrogen in urine and faeces}

Total $\mathrm{N}$ content in urine was determined by a pyrochemiluminescent technique according to Grimble et al. (1988) using the Antek $771 \mathrm{~N}$ analyser (Antek Instruments, Inc., Houston, TX, USA). Approximately $0 \cdot 2 \mathrm{~g}$ faecal powder was transferred to a Kjeldahl digestion tube, $10 \mathrm{ml}$ $18 \mathrm{M}-\mathrm{H}_{2} \mathrm{SO}_{4}, 2 \mathrm{ml}$ water and one Kjeltab were added and digestion performed at $380^{\circ}$ for $1 \mathrm{~h}$. $\mathrm{N}$ content in the digested samples was determined as previously described for urine.

\section{Quantification of total insulin-like growth factor-I in serum and tissues}

IGF-I was extracted from gastrocnemius muscles by addition of $5 \mathrm{ml}$ extraction solution $(5.0 \mathrm{ml}$ trasylol, $5.7 \mathrm{ml}$ concentrated acetic acid and $89.3 \mathrm{ml}$ distilled water $/ \mathrm{g}$ tissue, homogenized using a polytron homogenizer and centrifuged. The supernatant fraction was evaporated and reconstituted with $100 \mu \mathrm{l}$ distilled water before IGF-I assay.

Total IGF-I in serum and tissue extracts was determined with a radioimmunoassay method after acid-ethanol extraction of the IGF-binding proteins (Daughaday et al. 1980). In the assay a polyclonal IGF-I antibody (GroPep, Adelaide, 
Australia) was used and rhIGF-I (Batch 62526 DSQ-93; Pharmacia, Kabi Peptide Hormones, Stockholm, Sweden) was used as the standard. To avoid interference from IGFbinding protein residues remaining after acid-ethanol extraction, a truncated ${ }^{125} \mathrm{I}-\mathrm{des}(1-3)$ IGF-I (Pharmacia, Kabi Peptide Hormones) tracer was employed (Bang et al. 1991). In muscle extracts the prevalence of such residues after acid-ethanol extraction was checked with Western ligand blots. However, no bands could be observed, which means that the IGF-binding proteins had been removed or that their concentration was low. A muscle extract sample was also diluted in several steps. When IGF-I was determined in these dilutions and plotted against a standard curve, the slope of these curves was the same. Results are expressed as $\mathrm{ng} / \mathrm{ml}$ serum or $\mathrm{ng} / \mathrm{g}$ wet weight of tissue, without correcting for extraction losses. The intra-assay CV was $4 \cdot 1 \%$ and the inter-assay CV $10 \%$.

\section{Solution hybridization assay of $m R N A$}

IGF-I mRNA analysis was performed as described by Möller et al. (1991). Briefly, total nucleic acid was prepared from tissues as described by Durnam \& Palmiter (1983) and IGF-I mRNA quantification was achieved using an RNA probe radiolabelled with ${ }^{35} \mathrm{~S}$-UTP. The radioactive probe and the unlabelled IGF-I mRNA strand were prepared according to the method of Mathews et al. (1986). The DNA clone used was a 153 base-pair genomic subclone (in pSP64 in both orientations) of mouse IGF-I corresponding to exon 3 (by analogy to human IGF-I). RNase-resistant radioactivity was precipitated with TCA and collected on glass fibre filters (Whatman, Labora, Sollentuna, Sweden). The radioactivity retained on the filters was counted in a liquid scintillation counter (LKB, Uppsala, Sweden) and the values obtained were compared with a standard curve prepared with known amounts of IGF-I mRNA. DNA content in total nucleic acid samples was measured by a fluorometric assay as described by Labarca \& Paigen (1980). Results are expressed as the amount of IGF-I mRNA/DNA (attomol/ $\mu \mathrm{g}$ ). Each total nucleic acid sample was assayed in triplicate.

\section{Calculations and statistics}

$\mathrm{N}$ balance was calculated based on $\mathrm{N}$ intake and excretion in urine and faeces by using the following formula: $\mathrm{N}$ balance $=$ total $\mathrm{N}$ intake $-($ urine $\mathrm{N}+$ faeces $\mathrm{N})$. Both $\mathrm{N}$ balance and $\mathrm{N}$ intake were expressed in relation to the mean weight of animals during the experimental period. All data were analysed by a two-way ANOVA in which protein level and treatment were the main sources of variation. After this analysis, $t$ tests were used to detect significant differences. The calculations were executed by the general linear models procedure of the Statistical Analysis Systems program (SAS Institute Inc., 1985). Values were considered to be significantly different if $P$ values were less than $0 \cdot 05$.

\section{Results}

\section{Feed and nitrogen consumption}

When estimated over all infusion regimens, mean intakes of the HP and LP diets were comparable: 204 (SD 16.6) g and 191 (sD 13.8) g respectively. Since the diets were isoenergetic, this means that intakes of metabolizable energy were comparable, whereas intakes of $\mathrm{N}$ were approximately doubled in animals given the HP diet. Intake of the HP diet was not significantly affected by rhGH or rhIGF-I infusions. However, among animals given the LP diet, rhGH was found to increase $\mathrm{N}$ consumption by 8 and $13 \%$ in comparison with saline and rhIGF-I $(P<0.05)$ respectively (Fig. 1(a)).

\section{Nitrogen balance}

$\mathrm{N}$ balance after the $14 \mathrm{~d}$ study period is shown in Fig. 1(b). Among rats given the LP diet, the infusion of rhGH increased $(P<0.05) \mathrm{N}$ balance by $27 \%$ compared with saline and by $34 \%$ in comparison with rhIGF-I $(P<0.02)$. No statistically significant difference was evident between LP diet groups receiving saline or rhIGF-I. However, rhIGF$\mathrm{I}$, if infused into animals receiving the HP diet, was found to produce a $22 \%$ increase $(P<0.05)$ in $\mathrm{N}$ balance compared with saline, whereas on this diet no such effect was seen with rhGH.

\section{Insulin-like growth factor-I mRNA levels in skeletal muscles}

It was observed that rats on the LP diet receiving infusions of saline had significantly $(P<0.02)$ reduced levels of muscle IGF-I mRNA compared with rats given the HP diet and the same type of infusion. This reduction was in the order of $75 \%$. In all instances, both rhGH and rhIGF-I appeared to increase muscle IGF-I mRNA. However, due to great individual variation between animals this trend was generally not statistically significant, except in one case. Thus, in rats on the LP diet, infusion of rhIGF-I was associated with significantly $(P<0.05)$ higher levels of IGF-I mRNA in comparison with saline (Fig. 2(a)).

\section{Muscle tissue insulin-like growth factor-I concentration}

Among the saline-treated rats there was a significant $(P<0.05)$ reduction in the muscle tissue concentration of IGF-I in the animals fed on the LP diet, compared with the group eating the HP diet (Fig. 2(b)). This concentration appeared to be somewhat restored after rhGH and rhIGF-I infusions, but in neither case was statistical significance reached.

Animals given the HP diet showed significantly $(P<0.03)$ higher IGF-I concentrations after IGF-I administration. rhGH appeared to raise the concentration but significance was not obtained in comparison with the saline-treated animals (Fig. 2(b)).

\section{Circulating insulin-like growth factor-I}

At day 14, animals infused with saline and given the LP diet showed significantly $(P<0.02)$ reduced serum IGF-I concentrations compared with initial values (Table 2). Infusions of rhGH failed to increase the IGF-I levels which remained significantly $(P<0.02)$ decreased. In 



Fig. 1. Effects of continuous infusions of saline (眯), recombinant human growth hormone ( $\square$ ) and recombinant human insulin-like growth factor-I $(\mathbb{N})$ on (a) nitrogen intake and (b) nitrogen balance in rats fed on a low-protein (LP) or a high-protein (HP) diet for a $14 \mathrm{~d}$ treatment period. Values are means for eight rats, with their standard deviations represented by vertical bars. ${ }^{a, b, c, d}$ Bars not sharing a common letter were significantly different, $P<0.05$. 



Fig. 2. Effects of continuous infusions of saline (朆), recombinant human growth hormone $(\square)$ and recombinant human insulin-like growth factor-I $(I G F-I)(\mathbb{Q})$ on (a) muscle IGF-I mRNA levels and (b) muscle IGF-I concentration in rats fed a low-protein (LP) or a high-protein (HP) diet, after a $14 \mathrm{~d}$ study period. Values are means for eight rats, with standard deviations represented by vertical bars. ${ }^{\mathrm{a}, \mathrm{b}, \mathrm{c}}$ Bars not sharing a common letter were significantly different, $P<0.05$. 
Table 2. Serum insulin-like growth factor-I (IGF-I) concentrations (ng/ $\mathrm{ml}$ ) in rats given either a low-protein (LP) or a high-protein (HP) diet together with continuous infusions of saline, recombinant human growth hormone (rhGH) or recombinant human IGF-I (rhIGF-I)†

(Mean values and standard deviations for eight rats per group)

\begin{tabular}{lccccc}
\hline \multirow{2}{*}{ Diet ... } & \multicolumn{2}{c}{ HP } & & \multicolumn{2}{c}{ LP } \\
\cline { 2 - 3 } \cline { 5 - 6 } & Mean & SD & & Mean & SD \\
\hline Before treatment (day 0) & 554 & 127 & & 652 & 131 \\
After treatment (day 14) & & & & \\
$\quad$ Saline (9 g NaCl/I) & 575 & 50 & & $456^{*}$ & 32 \\
rhGH & 516 & 30 & & $385^{*}$ & 51 \\
rhlGF-I & $1998^{*}$ & 224 & & $1640^{*}$ & 370 \\
\hline
\end{tabular}

Mean values were significantly different from the corresponding values for day $0,{ }^{*} P<0.05$.

†For details of diets and procedures, see Table 1 and pp. 146-147.

contrast, infusion of rhIGF-I significantly $(P<0.0001)$ increased circulating IGF-I levels above initial values. Animals on the HP diet had circulating IGF-I levels which were similar to initial ones, after saline and rhGH treatments, but as expected, IGF-I levels increased dramatically $(P<0 \cdot 0001)$ after rhIGF-I infusion (Table 2).

\section{Discussion}

It is well established that GH not only stimulates linear growth (Nilsson et al. 1994) but also has a more general protein anabolic effect (Hizuka et al. 1986; Ullman \& Oldfors, 1989; Snyder et al. 1990; Fryburg et al. 1991). The protein anabolic effect of IGF-I appears to be more variable (Breier et al. 1986; Takahashi et al. 1990; Douglas et al. 1991; Thissen et al. 1991b; Tomas et al. 1991; Clemmons et al. 1992). The reason for this variability might be that the protein anabolic effect of IGF-I is relatively more dependent on a rich supply of amino acids (Phillips, 1986). The main purpose of the present animal study was to examine further the interaction between dietary protein level and the protein anabolic effects of rhGH and rhIGF-I.

\section{Effects of dietary protein level alone}

A reduction of the dietary protein level from $222 \mathrm{~g} / \mathrm{kg}$ (HP diet) to $82 \mathrm{~g} / \mathrm{kg}$ (LP diet) was associated with decreases in $\mathrm{N}$ intake, total $\mathrm{N}$ balance, circulating IGF-I levels, muscle IGF-I levels and muscle IGF-I mRNA levels. It has previously been observed that a reduction in dietary protein supply decreases circulating levels of IGF-I (Maes et al. 1988; Thissen et al. 1990), whereas the effects on muscle IGF-I and IGF-I mRNA levels are less well known. It has, however, been observed that a low intake of dietary protein blocks some of the mechanisms involved in IGF-I translation (Thissen et al. 1991a; VandeHaar et al. 1991). Protein restriction has also been shown to decrease slightly the mean size of polysomes with a possible effect on the efficiency of translation (Thissen \& Underwood, 1992). Direct effects on the control of IGF-I expression by amino acid deprivation were recently demonstrated in primary cultures of rat hepatocytes (Harp et al. 1991; Thissen et al. 1994).

\section{Effects of rhGH and rhIGF-I}

Despite the dramatic changes in IGF-I physiology induced by the LP diet, it could be observed that rhGH significantly increased $\mathrm{N}$ balance in rats on this diet. Although rhGH was associated with a slight increase in $\mathrm{N}$ intake, this change was not of an order to explain the increase in $\mathrm{N}$ balance. Thus, it seems as if rhGH mainly promoted $\mathrm{N}$ balance by increasing metabolic efficiency. In human subjects such anabolic effects have been observed in energy-restricted obese and normal subjects (Snyder et al. 1990; Clemmons et al. 1992). The present study suggests that rhGH has the potential to increase $\mathrm{N}$ balance even during moderate protein-restriction. It is of interest to know which tissues are involved in the increased retention of N. Both skeletal muscles (Campbell et al. 1990; Malmlöf et al. 1995) and visceral organs (Okamura et al. 1989; Pell \& Bates, 1992) have been implicated in this context.

Recent in vivo studies have shown that administration of exogenous IGF-I can reproduce some of the protein anabolic actions of GH (Behringer et al. 1990; Tomas et al. 1993; Malmlöf et al. 1995). Although this type of observation might imply that the anabolic effects of $\mathrm{GH}$ are in fact mediated by IGF-I, this question is still not resolved.

In this study it was observed that in rats on the LP diet, serum IGF-I concentrations were not increased by rhGH. This implies that circulating IGF-I does not mediate the protein anabolic effects of rhGH. Similar results have been reported earlier in protein-deficient rats and surgically traumatized pigs (Thissen et al. 1990; Bolze et al. 1991; Douglas et al. 1991; Malmlöf et al. 1995). The lack of increase in circulating IGF-I does not exclude the possibility that the protein anabolic effect of rhGH in rats on the LP diet was mediated by an increase in local production of IGF-I. It is, however, unlikely that this happened since the muscle concentration of IGF-I and its mRNA were not significantly increased by rhGH administration. In this connection it must, however, be pointed out that our data do not exclude a modest increase, only that we were unable to verify such an increase statistically. The uncertainty on this point was mainly due to large individual variation. The variation in IGF-I transcription has been reported previously (Strauss \& Takemoto, 1990; Hayden et al. 1994) and although the molecular basis of this variation is not completely understood, one probable explanation is that the IGF-I gene is transcribed in a pulsatile manner. Unfortunately, this uncertainty obscures the conclusion that $\mathrm{GH}$ in a protein-deficient situation directly increases the efficiency of amino acid conversion into protein without involvement of locally produced IGF-I. Future studies will have to clarify this point.

When rhGH was infused into rats on the HP diet only a modest $(3 \%)$ and statistically insignificant further increase in $\mathrm{N}$ balance was observed. This finding is surprising since in the literature other authors have found that the anabolic effects of $\mathrm{GH}$ are better expressed when the dietary protein level is high (MacRae et al. 1991; Thissen et al. 1991b). One of the most systematic approaches to this question has been reported by Campbell et al. (1990). In that study there seemed to be a lower threshold of dietary protein intake. 
Below this no effects of GH could be observed. Our data obtained with the HP diet seem to imply that there might also be an upper level of dietary protein intake where protein deposition is maximally stimulated by diet alone and beyond which no further improvements with $\mathrm{GH}$ can be expected. Exactly where this limit lies might be dependent on factors like species, nature of dietary protein, dosage regimen and type of $\mathrm{GH}$ used. Therefore, it is possible that animals on the HP diet would have responded, had the dose of $\mathrm{GH}$ been higher than in this study. Further studies are planned to investigate this possibility.

Following administration of rhIGF-I to rats on the LP diet no anabolic effect was seen, whereas the same peptide significantly improved $\mathrm{N}$ balance in rats given the HP diet. These observations are in accordance with the fact that IGF-I has been reported to be ineffective in promoting anabolic functions in N-restricted rats (Thissen et al. 1991a), whereas studies in human subjects given a lowenergy-normal-protein diet have shown effects (Clemmons et al. 1992). Clearly, observations of that kind also introduce another interesting question, namely the role of nutrition in determining the availability of IGF-I at the tissue level. After IGF-I administration in both the LP- and HP-diet groups, circulating levels of IGF-I increased dramatically. In the LP group tissue levels were not affected by this increase, whereas in the HP diet group very high concentrations of this peptide were found in muscle tissues. Following administration of rhIGF-I, the IGF-I mRNA levels were increased to the same level irrespective of diet given. Therefore, it appears reasonable to believe that the significant increase of muscle IGF-I in rats on the HP diet could be associated with an increase in the translation of IGF-I mRNA into IGF-I. In fact it has been observed previously that the dietary protein level influences IGF-I translation (Thissen et al. 1991a; VandeHaar et al. 1991).

Another possible explanation for the increase in tissue IGF-I following administration of rhIGF-I in rats on the HP diet would be an increase in trans-capillary transport of circulating IGF-I. The present study was not designed to study this and we did not measure IGF-binding proteins. Although it is well established that IGF-I binding proteins are influenced by nutrition, the further implications of this in terms of trans-capillary IGF-I transport are still not clear.

In conclusion, we have found that rhGH exerts a protein anabolic function even during protein-restriction, whereas IGF-I is dependent on a rich supply of dietary protein in order to promote $\mathrm{N}$ balance of growing rats. We have also found that in situations where IGF-I is observed to be anabolic, the tissue concentrations of this hormone are high.

\section{Acknowledgements}

The authors thank Dr Gunnar Norstedt, Karolinska Institute, Novum Research Park, Huddinge, Sweden for providing the IGF-I probe and assistance with the mRNA analysis; and $\mathrm{Mr}$ Peter Jönsson for performing the statistical analyses of the data. M.S-G. is grateful to the International Program in the Chemical Sciences (IPICS), Uppsala University, Sweden for the financial support to the project COL:01 and for the fellowships granted to W.M., A.B., M.T.O. and S.C-R.

\section{References}

Bang P, Eriksson U, Sara V, Wivall I-L \& Hall K (1991) Comparison of acid ethanol extraction and acid gel filtration prior to IGF-I and IGF-II radioimmunoassays. Improvement of determination in acid ethanol extracts by the use of truncated IGF-I as radioligand. Acta Endocrinologica 124, 620-629.

Behringer RR, Lewin TM, Quaife CJ, Palmiter RD, Brinster RL \& D'Ercole AJ (1990) Expression of insulin-like growth factor I stimulates normal somatic growth in growth-hormone deficient transgenic mice. Endocrinology 127, 1033-1040.

Bolze MS, Osborne JM, Vecbastiks KA \& White ME (1991) Insulin-like growth factor binding proteins in rats respond to fasting and the protein and energy content of the re-feeding diet. Journal of Nutritional Biochemistry 2, 623-628.

Breier BH, Bass JJ, Butler JH \& Gluckman PD (1986) The somatotrophic axis in young steers: influence of nutritional status on pulsatile release of growth hormone and circulating concentrations of insulin-like growth factor-I. Journal of Endocrinology 111, 209-215.

Campbell RG, Johnson RJ, King RH, Taverner MR \& Meisinger DJ (1990) Interaction of dietary protein content and exogenous porcine growth hormone administration on protein and lipid accretion rates in growing pigs. Journal of Animal Science $\mathbf{6 8}$, 3217-3225.

Clemmons DR, Smith-Banks A \& Underwood LE (1992) Reversal of diet-induced catabolism by infusion of recombinant insulinlike growth factor-I in humans. Journal of Clinical Endocrinology and Metabolism 75, 234-238.

Clemmons DR \& Underwood LE (1991) Nutritional regulation of IGF-I and IGF-I binding proteins. Annual Review of Nutrition 11, 393-412.

Dardevet D, Manin M, Sornet C, Attaix D, Baracos VE \& Grizard J (1994) Insulin-like growth factor-I and insulin resistance in skeletal muscles of adult and old rats. Endocrinology 134, 1475-1484.

Daughaday WH, Mariz IK \& Bleten SL (1980) Inhibition of access of bound somatomedin to membrane receptor and immunobinding sites: a comparison of radioreceptor and radioimmunoassay of somatomedin in native and acid-ethanol-extracted serum. Journal of Clinical Endocrinology and Metabolism 51, 781-788.

Daughaday WH \& Rotwein P (1989) Insulin-like growth factors I and II. Peptide, messenger ribonucleic acid and gene structures, serum and tissue concentrations. Endocrine Reviews 10, 68-91.

Dodson MW, Allen RE \& Hossner KL (1985) Ovine somatomedin multiplication - stimulating activity and insulin promote skeletal muscle satellite cell proliferation in vitro. Endocrinology 117, 2357-2363.

Douglas RG, Gluckman PD, Ball K, Breier B \& Shaw JH (1991) The effects of infusion of insulin-like growth factor (IGF)-I, IGF-II, and insulin on glucose and protein metabolism in fasted lambs. Journal of Clinical Investigation 88, 614-622.

Durnam DM \& Palmiter RD (1983) A practical approach for quantitating specific mRNAs by solution hybridization. Analytical Biochemistry 131, 385-393.

Eriksson S, Sanne S \& Thomke S (1976) Fodermedelstabeller och ut-fodringsrekomendationer (Feed tables and feeding recommendations), pp. 36-41. Borås: LTs förlag.

Fryburg DA, Gelfand RA \& Barrett EJ (1991) Growth hormone acutely stimulates forearm muscle protein synthesis in normal humans. American Journal of Physiology 260, E499-E504.

Gelfand RA \& Barrett EJ (1987) Effect of physiological hyperinsulinemia on skeletal muscle protein synthesis and breakdown in man. Journal of Clinical Investigation 80, 1-6.

Grant AL, Helferich WG, Kramer SA, Merkel RA \& Bergen WG (1991) Administration of growth hormone to pigs alters the 
relative amount of insulin-like growth factor-I mRNA in liver and skeletal muscle. Journal of Endocrinology 130, 331-338.

Grimble GK, West MF, Acuti AB, Rees RG, Hunjan MK, Webster JD, Frost PG \& Silk DB (1988) Assessment of an automated chemiluminescence nitrogen analyzer for routine use in clinical nutrition. Journal of Parenteral and Enteral Nutrition 12, $100-106$.

Harp JB, Goldstein S \& Phillips LS (1991) Nutrition and somatomedin. XXIII. Molecular regulation of IGF-I by amino acid availability in cultured hepatocytes. Diabetes 40, 95-101.

Hayden JM, Marten NW, Burke EJ \& Straus DS (1994) The effect of fasting on insulin-like growth factor-I nuclear transcript abundance in rat liver. Endocrinology 134, 760-768.

Hizuka N, Takano K, Shizume K, Asakawa K, Miyakawa M, Tanaka Y \& Horikawa R (1986) Insulin-like growth factor-I stimulates growth in normal growing rats. European Journal of Pharmacology 125, 143-146.

Isgaard J, Nilsson A, Vikman K \& Isaksson OGP (1989) Growth hormone regulates the level of insulin-like growth factor-I mRNA in rat skeletal muscle. Journal of Endocrinology 120, 107-112.

Labarca C \& Paigen K (1980) A simple, rapid and sensitive DNA assay procedure. Analytical Biochemistry 102, 344-352.

MacRae JC, Bruce LA, Hovell FD DeB, Hart IC, Inkster J, Walker A \& Atkinson T (1991) Influence of protein nutrition on the response of growing lambs to exogenous bovine growth hormone. Journal of Endocrinology 130, 53-61.

Maes M, Amand Y, Underwood LE, Maiter D \& Ketelslegers JM (1988) Decreased serum insulin-like growth factor I response to growth hormone in hypophysectomized rats fed a low protein diet: evidence for a postreceptor defect. Acta Endocrinologica 117, 320-326.

Malmlöf K, Cortova Z, Saxerholt H, Karlsson E, ArrheniusNyberg V \& Skottner A (1995) Effects of insulin-like growth factor-I and growth hormone on the net flux of amino acids across the hind limbs in the surgically traumatized pig. Clinical Science 88, 285-292.

Mathews LS, Norstedt G \& Palmiter RD (1986) Regulation of insulin-like growth factor I gene expression by growth hormone. Proceedings of the National Academy of Sciences USA 83, 9343-9347.

Möller C, Arner P, Sonnenfeld T \& Norstedt G (1991) Quantitative comparison of insulin-like growth factor mRNA levels in human and rat tissues analysed by a solution hybridization assay. Journal of Molecular Endocrinology 7, 213-222.

Nilsson A, Ohlsson C, Isaksson OGP, Lindahl A \& Isgaard J (1994) Hormonal regulation of longitudinal bone growth. European Journal of Clinical Nutrition 48, S150-S160.

Okamura K, Okuma T, Tabira Y \& Miyauchi Y (1989) Effect of administered human growth hormone on protein metabolism in septic rats. Journal of Parenteral and Enteral Nutrition 13, $450-454$

Pell JM \& Bates PC (1992) Differential actions of growth hormone and insulin-like growth factor-I on tissue protein catabolism in dwarf mice. Endocrinology 130, 1942-1950.

Phillips LS (1986) Nutrition, somatomedins and the brain. Metabolism 35, 78-87.

Press M (1988) Growth hormone and metabolism. Diabetes/ Metabolism Reviews 4, 391-414.
SAS Institute Inc. (1985) SAS User's Guide, Statistics, 5th ed. Cary, NC: SAS Institute Inc.

Skottner A, Clark RG, Robinson ICAF \& Fryklund L (1987) Recombinant human insulin-like growth factor: testing the somatomedin hypothesis in hypophysectomized rats. Journal of Endocrinology 112, 123-132.

Snyder DK, Underwood LE \& Clemmons DR (1990) Anabolic effects of growth hormone in obese diet-restricted subjects are dose dependent. American Journal of Clinical Nutrition 52, 431-437.

Straus DS \& Takemoto CD (1990) Effect of dietary protein deprivation on insulin-like growth factor (IGF)-I and -II, IGF binding protein-2 and serum albumin gene expression in rat. Endocrinology 127, 1849-1860.

Takahashi S, Kajikawa M, Umezawa T, Takahashi S-I, Kato H, Miura Y, Nam TJ, Noguchi T \& Naito H (1990) Effect of dietary proteins on the plasma immunoreactive insulin-like growth factor-1/somatomedin C concentration in the rat. British Journal of Nutrition 63, 521-534.

Thissen JP, Pucilowska JB \& Underwood LE (1994) Differential regulation of insulin-like growth factor-I (IGF-I) and IGF binding protein-I messenger ribonucleic acid by amino acid availability and growth hormone in rat hepatocyte primary culture. Endocrinology 134, 1570-1576.

Thissen JP, Triest S, Moats-Staats BM, Underwood LE, Mauerhoof T, Maiter D \& Ketelslegers JM (1991a) Evidence that pretranslational and translational defects decrease serum insulin-like growth factor-I concentrations during dietary proteinrestriction. Endocrinology 129, 429-435.

Thissen JP, Triest S, Underwood LE, Maes M \& Ketelslegers JM (1990) Divergent responses of serum insulin-like growth factor-I and liver growth hormone $(\mathrm{GH})$ receptors to exogenous $\mathrm{GH}$ in protein restricted rats. Endocrinology 126, 908-913.

Thissen JP \& Underwood LE (1992) Translational status of the insulin-like growth factor-I mRNAs in liver of protein-restricted rats. Endocrinology 132, 141-147.

Thissen JP, Underwood LE, Maiter D, Maes M, Clemmons DR \& Ketelslegers JM (1991b) Failure of insulin-like growth factor-I infusion to promote growth in protein-restricted rats despite normalization of serum IGF-I concentrations. Endocrinology 128, 885-890.

Tomas FM, Knowles SE, Chandler CS, Francis GL, Owens PC \& Ballard FJ (1993) Anabolic effects of insulin-like growth factorI (IGF-I) and IGF-I variant in normal female rats. Journal of Endocrinology 137, 413-421.

Tomas FM, Knowles SE, Owens PC, Read LC, Chandler CS, Gargosky SE \& Ballard FJ (1991) Effects of full-length and truncated insulin-like growth factor-I on nitrogen balance and muscle protein metabolism in nitrogen-restricted rats. Journal of Endocrinology 128, 97-105.

Ullman M \& Oldfors A (1989) Effects of growth hormone on skeletal muscle. I. Studies on normal adult rats. Acta Physiologica Scandinavica 135, 531-536.

VandeHaar MJ, Moats-Staats BM, Davenport ML, Walker JL, Ketelslegers JM, Sharma BK \& Underwood LE (1991) Reduced serum concentrations of insulin-like growth factor-I (IGF-I) in protein-restricted growing rats is accompanied by reduced IGF-I mRNA levels in liver and skeletal muscle. Journal of Endocrinology 130, 305-312. 